\title{
Probiotic Properties and Potentiality of Lactiplantibacillus plantarum Strains for the Biological Control of Chalkbrood Disease
}

\author{
Massimo Iorizzo ${ }^{1, *(1)}$, Bruno Testa ${ }^{1}\left(\mathbb{D}\right.$, Sonia Ganassi ${ }^{1, *}$, Silvia Jane Lombardi ${ }^{1}$, Mario Ianiro ${ }^{1}$, \\ Francesco Letizia ${ }^{1}$, Mariantonietta Succi ${ }^{1}$, Patrizio Tremonte ${ }^{1}$, Franca Vergalito ${ }^{1}$, Autilia Cozzolino ${ }^{1}$, \\ Elena Sorrentino $^{1}\left(\mathbb{D}\right.$, Sonia Petrarca ${ }^{2}$, Antonio De Cristofaro ${ }^{1}$ (D) and Raffaele Coppola ${ }^{1}$ (D) \\ 1 Department of Agriculture, Environmental and Food Sciences, University of Molise, Via De Sanctis, \\ 86100 Campobasso, Italy; bruno.testa@unimol.it (B.T.); silvia.lombardi@unimol.it (S.J.L.); \\ m.ianiro@studenti.unimol.it (M.I.); f.letizia@studenti.unimol.it (F.L.); succi@unimol.it (M.S.); \\ tremonte@unimol.it (P.T.); franca.vergalito@unimol.it (F.V.); autilia.cozzolino@unimol.it (A.C.); \\ sorrentino@unimol.it (E.S.); decrist@unimol.it (A.D.C.); coppola@unimol.it (R.C.) \\ 2 Conaproa, Consorzio Nazionale Produttori Apistici, 86100 Campobasso, Italy; sonia_petrarca@libero.it \\ * Correspondence: iorizzo@unimol.it (M.I.); sonia.ganassi@unimol.it (S.G.)
}

Citation: Iorizzo, M.; Testa, B.; Ganassi, S.; Lombardi, S.J.; Ianiro, M.; Letizia, F.; Succi, M.; Tremonte, P.; Vergalito, F.; Cozzolino, A.; et al. Probiotic Properties and Potentiality of Lactiplantibacillus plantarum Strains for the Biological Control of Chalkbrood Disease. J. Fungi 2021, 7, 379. https://doi.org/10.3390/ jof7050379

Academic Editor:

Jennifer Geddes-McAlister

Received: 7 March 2021

Accepted: 9 May 2021

Published: 12 May 2021

Publisher's Note: MDPI stays neutral with regard to jurisdictional claims in published maps and institutional affiliations.

Copyright: (c) 2021 by the authors. Licensee MDPI, Basel, Switzerland. This article is an open access article distributed under the terms and conditions of the Creative Commons Attribution (CC BY) license (https:// creativecommons.org/licenses/by/ $4.0 /)$.

\begin{abstract}
Ascosphaera apis is an entomopathogenic fungus that affects honeybees. In stressful conditions, this fungus (due not only to its presence, but also to the combination of other biotic and abiotic stressors) can cause chalkbrood disease. In recent years, there has been increasing attention paid towards the use of lactic acid bacteria (LAB) in the honeybees' diets to improve their health, productivity and ability to resist infections by pathogenic microorganisms. The screening of 22 strains of Lactiplantibacillus plantarum, isolated from the gastrointestinal tracts of honeybees and beebread, led to the selection of five strains possessing high antagonistic activity against $A$. apis. This study focused on the antifungal activity of these five strains against A. apis DSM 3116 and DSM 3117 using different matrices: cell lysate, broth culture, cell-free supernatant and cell pellet. In addition, some functional properties and the antioxidant activity of the five L. plantarum strains were evaluated. All five strains exhibited high antagonistic activity against $A$. apis, good surface cellular properties (extracellular polysaccharide (EPS) production and biofilm formation) and antioxidant activity. Although preliminary, these results are encouraging, and in future investigations, the effectiveness of these bacteria as probiotics in honeybee nutrition will be tested in vivo in the context of an eco-friendly strategy for the biological control of chalkbrood disease.
\end{abstract}

Keywords: Ascosphaera apis; chalkbrood disease; Lactiplantibacillus plantarum; biocontrol; honeybee

\section{Introduction}

The fungus Ascosphaera apis, belonging to the heterothallic Ascomycota phylum, is a major and widespread pathogen of honeybee (Apis mellifera) broods, causing chalkbrood disease and larval death [1]. This disease is economically important since it results in significant losses of both honeybees (under certain circumstances, it can kill colonies) and colony productivity [2], and indications suggest that its incidence may be increasing [3]. Recent research demonstrated that $A$. apis infection, together with other biotic and abiotic factors, induces oxidative stress and impairs the antioxidant defensive capacity of honeybee larvae [4].

Pathogenesis occurs when larvae ingest sexual spores of $A$. apis with their food. Inside the gut, the spores find the necessary anaerobic environment for their germination and extend into hyphal growth [5]. The infected larvae rapidly reduce their food consumption and then stop eating. The persistence of ascospores, which remain viable for many years on all surfaces inside the hive, provides a continuous source of infection [6]. Honeybees have several defense mechanisms to resist chalkbrood disease, including hygienic behavior [7]. However, if the potentially sporulating chalkbrood mummies are removed, hygienic 
behavior can increase rather than decrease transmission by exposing more individuals to the spores [8]. In addition, social insect species, such as A. mellifera, exhibit behaviors such as flower sharing to collect pollen and nectar, which might increase the transmission of persistent chalkbrood spores between colonies [9]. Drifting workers and drones may also contribute to the spread of infection [10].

Chalkbrood disease depends on several interacting aspects, such as the environment, the biological characteristics of both the host and the fungus (which may influence fungal pathogenesis and the transmission of the disease) and possible co-infections. Outbreaks may be increased by the disruption of the beneficial microbial community within a colony [11]. There is increasing knowledge on both the composition and the functions of the honeybee gut microbiota, which has led to the discovery of evidence of a link between balanced gut microbiota and honeybee health [12-15]. In particular, there is some evidence that A. mellifera gut microbiota may exhibit antifungal activity against $A$. apis [16-18]. A broad range of chemotherapeutic compounds have been tested to control chalkbrood disease over the years [19-22], but none have been able to control it properly. Furthermore, pesticides and antifungal chemicals have had serious impacts on the environment, honey quality and honeybee colonies themselves [23]. Therefore, there is great interest in developing alternative chalkbrood-controlling strategies.

In an interesting review, Gaggia et al. [24] provided an overview of beneficial microorganism applications for the treatment of the main honeybee pathogens and their benefits in beekeeping production systems. Some more recent research has confirmed that the use of lactic acid bacteria (LAB) as probiotics could prevent certain diseases and improve honeybee health [25-28]. In particular, Tejerina et al. [29] recently demonstrated that the application of LAB (Lactobacillus melliventris, Lactobacillus helsingborgensis and Lactobacillus kunkeei) in sugar syrup over 5 months reduced larval mummification in chalkbrood disease by over $80 \%$.

These data highlight that the administration of probiotic lactic bacteria in the honeybee diet can be a valid strategy for the biological control of chalkbrood disease. Lactiplantibacillus plantarum (formerly Lactobacillus plantarum [30]) is an important and ubiquitous LAB species characterized by extreme adaptability and genome plasticity. It has been isolated in many different environmental niches, such as fruit, vegetables, all types of fermented foods, meat and fish [31-33]. L. plantarum strains have also been isolated from different honeybee species [34-37]. Several authors have demonstrated that $L$. plantarum colonizes the adult Drosophila melanogaster gut and that it influences different aspects of the insect's development and life, exerting a growth-promoting effect on larvae under nutrient scarcity [38-42]. Several authors have proved that L. plantarum has a broad capacity to inhibit the growth of different pathogens, and different strains exert inhibitory activity towards bacteria and fungi. In addition, chemically different compounds with antibacterial and antifungal activity have been characterized in culture filtrates [43-46], L. plantarum also exhibits antagonist activity against Paenibacillus larvae, the causative agent of the quarantine disease American foulbrood, which affects A. mellifera larvae and pupae [27,28,30-47]. Over the years, several studies have obtained relevant data supporting the probiotic properties of $L$. plantarum $[48,49]$.

Suggested mechanisms by which probiotics may benefit the gut environment and the health of the host include improving intestinal barrier function through effects on the epithelium and mucus lining, producing antimicrobial substances, competing with pathogenic bacteria and antioxidative activity [50]. The ability of microorganisms to colonize is often considered one of the main selection criteria for potential probiotics, as their colonization is important for their activity. In addition, both their longer permanence in the mucosa of the host and their action as a biological barrier reduce or prevent pathogen colonization [51-54]. The ability of probiotic bacteria to adhere to intestinal epithelial cells involves extracellular polysaccharide (EPS) production and biofilm formation [51-54], and several L. plantarum strains are able to do both $[48,49]$. 
In this research, the antagonistic activity of five L. plantarum strains, isolated from the honeybee gut and beebread toward $A$. apis was assessed. The abilities of these lactic bacteria to produce EPSs and biofilms, as well as their antioxidant activity, were also evaluated. The final goal of this study was to evaluate the use of these L. plantarum strains as probiotics in the honeybee diet, and their potential use for the biocontrol of chalkbrood disease.

\section{Materials and Methods}

\subsection{Microbial Cultures}

In this study, 22 L. plantarum strains isolated from beebread, the midgut and the honey stomach of $A$. mellifera L. honeybees were used (Table S1). These bacteria belong to the Di.A.A.A. (Department of Agricultural, Environmental and Food Sciences) collection of the University of Molise [37]. As reference, A. apis DSM 3116 and A. apis DSM 3117 cultures (DSMZ: German Collection of Microorganisms and Cell Cultures $\mathrm{GmbH}$ ) were used.

\subsection{Screening for Antifungal Activity}

The antifungal activity of the L. plantarum strains was assessed using the overlay method described by Magnusson et al. [55] with some modifications. The LAB strains were cultured in De Man, Rogosa and Sharpe (MRS) broth (Oxoid Ltd., Hampshire, UK) at $37^{\circ} \mathrm{C}$ for $12 \mathrm{~h}$. Then, they were inoculated with a central single streak of $2 \mathrm{~cm}$ on MRS agar plates, which were then incubated at $37^{\circ} \mathrm{C}$ for $24 \mathrm{~h}$ under anaerobic conditions (GasPack anaerobic system, Sigma-Aldrich; St. Louis, MO, USA).

Fungal cultures from A. apis DSM 3116 and A. apis 3117 were cultured in Malt Extract Agar (MEA) medium (Oxoid Ltd., Hampshire, UK) under aerobic conditions at $28{ }^{\circ} \mathrm{C}$ for 5 days. Then, a $6 \mathrm{~mm}$-diameter mycelial disc was removed, dissolved in physiological solution $(0.9 \% \mathrm{NaCl})$ and vortexed for $5 \mathrm{~min} ; 1 \mathrm{~mL}$ of the fungal suspension was then inoculated in a tube containing $10 \mathrm{~mL}$ of MEA soft agar $(0.7 \%$ agar), which had been overlaid on the MRS agar plates previously inoculated with the LAB strains as described above. As a control, a plate containing MEA with the fungal suspension but without bacteria was used. After $72 \mathrm{~h}$ of incubation at $37^{\circ} \mathrm{C}$, the inhibitory activity of the $L$. plantarum strains was measured as the diameter $(\mathrm{mm})$ of the clear zone around the bacterial streaks [56]. The tests were performed in triplicate.

\subsection{Antifungal Activity Determination}

\subsubsection{Spore Viability and Germination Test}

Fungal cultures of $A$. apis DSM 3116 and A. apis 3117 were cultured in MEA medium at $28{ }^{\circ} \mathrm{C}$ for 15 days in aerobiosis. A spore suspension was obtained by washing the ascospores that formed on the surfaces of plates with $5-10 \mathrm{~mL}$ of $0.01 \%$ sterile Tween80. The suspension was collected in a sterile $100 \mathrm{~mL}$ Erlenmeyer flask and loosened by shaking with sterile glass beads for $2 \mathrm{~h}$. The germination test was conducted according to the procedure described by Jensen et al. [57] with some modifications. Briefly, sterile Teflon-coated slides (TEKDON, Myakka City, FL, USA) were placed in a sterile Petri dish lined with wet filter paper. Then, $100 \mu \mathrm{L}$ of spore suspension (about $10^{7}$ spores $/ \mathrm{mL}$ ) was mixed with $400 \mu \mathrm{L}$ of GLEN medium [57] and $100 \mu \mathrm{L}$ of LAB culture (grown in MRS broth at $37^{\circ} \mathrm{C}$ for $24 \mathrm{~h}$ ), and $10 \mu \mathrm{L}$ of this spore/GLEN/LAB (SGL) mixture was placed onto the Teflon-coated slides. A spore/GLEN (SG) mixture without LAB cultures was used as a control. To stimulate germination, the Petri dish was exposed for $10 \mathrm{~min}$ to $9-13 \% \mathrm{CO}_{2}$ [58] using an AnaeroGen sachet in a $3.5 \mathrm{~L}$ jar (Oxoid; Basingstoke, UK), and after $32 \mathrm{~h}$ at $34{ }^{\circ} \mathrm{C}$ in aerobiosis, we counted the spores directly on the Teflon slide. About 100 spores were counted in three different fields of view on the slide using a phase contrast microscope at $400 \times$ magnification (Axioplan, Zeiss; Göttingen, Germany). Spores were considered germinated when the length of a hypha was longer than the length of the diameter of the spore. All the chemical compounds were supplied by Sigma-Aldrich (St. Louis, MO, USA). The tests were conducted in triplicate. 


\subsubsection{Inhibition of Radial Mycelial Growth}

The inhibitory activity against the A. apis 3116 and A. apis 3117 strains was determined according to Iorizzo et al. [59] using the following matrices of LAB cultures: broth culture (BC), cell-free supernatant (CFS), cell pellet (CP) and cell lysate (CL).

To obtain the matrices, each L. plantarum strain was cultivated in MRS broth and incubated at $37^{\circ} \mathrm{C}$ for $12 \mathrm{~h}$, reaching a cell concentration of $10^{8} \mathrm{CFU} / \mathrm{mL}$. This culture, without any treatment, was the $\mathrm{BC}$ matrix. Then, $5 \mathrm{~mL}$ of this bacterial culture was centrifuged at $8000 \mathrm{rpm}$ for $15 \mathrm{~min}$ at $4{ }^{\circ} \mathrm{C}$; the resulting supernatant was sterilized by filtration $(0.22 \mu \mathrm{m}$-pore-size cellulose acetate filter) to obtain the CFS matrix. For the $\mathrm{CP}$ matrix, the remaining pellet was washed and resuspended in $5 \mathrm{~mL}$ of physiological solution. To obtain the CL matrix, $5 \mathrm{~mL}$ of bacterial culture (BC) was centrifuged, and the pellet was washed, resuspended in $5 \mathrm{~mL}$ of physiological solution and then subjected to three cycles of sonication (Labsonic M; Sartorius, Germany) at $12 \mathrm{~W}$ for $30 \mathrm{~s}$, with a $60 \mathrm{~s}$ pause between the cycles to promote cellular lysis [60].

For each matrix (BC, CP, CFS and CL), $5 \mathrm{~mL}$ was added to $15 \mathrm{~mL}$ of MEA; this preparation was then poured into $90 \mathrm{~mm}$ Petri dishes. After the solidification of the medium, a mycelial disc ( $6 \mathrm{~mm}$ in diameter) of each A. apis strain was placed in the middle of the Petri dish, which was then incubated at $37^{\circ} \mathrm{C}$ under aerobiotic conditions. The antifungal activity was evaluated by measuring the hyphal radial growth (diameter) after 8 days of incubation and expressed as the percentage of inhibition using the following formula: $\% \mathrm{I}=[1-(\mathrm{Ds} / \mathrm{Dc})] \times 100$, where Ds is the hyphal diameter of the sample and Dc is the hyphal diameter of the control (MEA with fungus only). The experiments were performed in triplicate.

\subsection{Biofilm Production}

Biofilm production was evaluated as described by Cozzolino et al. [61] with some modifications. The L. plantarum strains were grown overnight at $37^{\circ} \mathrm{C}$ in MRS medium. The bacterial cells were harvested by centrifugation at $8000 \mathrm{rpm}$ for $10 \mathrm{~min}$ at $4{ }^{\circ} \mathrm{C}$, washed twice with phosphate-buffered saline (PBS) solution (Sigma-Aldrich, St. Louis, MO, USA), resuspended at $10^{6} \mathrm{CFU} / \mathrm{mL}$ in MRS broth without sugar and in MRS broth supplemented with $5 \%, 10 \%$ and $20 \%$ glucose, fructose or sucrose under aerobiotic and anaerobiotic conditions (GasPack anaerobic system, Sigma-Aldrich, St. Louis, MO, USA). Three $200 \mu \mathrm{L}$ aliquots of each bacterial suspension were transferred to a 96-well polystyrene microtiter plate. Wells filled with uninoculated culture media were used as negative controls. The microtiter plates were incubated for $24 \mathrm{~h}$ at $37^{\circ} \mathrm{C}$. The medium was then removed from each well, and the plates were washed three times with a sterile physiological solution to remove unattached cells. The remaining attached cells were fixed with $200 \mu \mathrm{L}$ of $99 \%$ methanol (Sigma-Aldrich, St. Louis, MO, USA) per well. After $15 \mathrm{~min}$, the methanol was removed, and the cells were left to dry. Then, $200 \mu \mathrm{L}$ of $2 \%$ Crystal Violet (Liofilchem; Roseto degli Abruzzi, Italy) was placed in the wells for $5 \mathrm{~min}$. The excess stain was then removed by washing three times with sterile saline solution. After the plates were air-dried, the adherent cells were resuspended in $160 \mu \mathrm{L}$ of $33 \%(v / v)$ glacial acetic acid (Sigma-Aldrich, St. Louis, MO, USA). The values of absorbance at $580 \mathrm{~nm}$, measured using an automated Multilabel Counter (PerkinElmer 1420), represented the biofilm formation capacity. The experiments were performed in triplicate.

\subsection{Exopolysaccharide (EPS) Assay \\ 2.5.1. Production and Isolation of EPSs}

Microbial EPSs are not permanently attached to the microbial cell surface and exist in two forms depending on their location: cell-bound EPSs, which closely adhere to the bacterial surface (bound exopolysaccharides; EPS-b), and EPSs that are released into the surrounding medium (released exopolysaccharides; EPS-r).

For each bacterium, $200 \mathrm{~mL}$ of MRS medium was inoculated with $1 \%(v / v)$ overnight precultures grown in the same medium. After incubation at $37^{\circ} \mathrm{C}$ for $48 \mathrm{~h}$, the cultures 
$\left(10^{8} \mathrm{CFU} / \mathrm{mL}\right)$ were centrifuged at $15,000 \times g$ for $15 \mathrm{~min}$ at $4{ }^{\circ} \mathrm{C}$. The pellets were washed twice with sterile water and then centrifuged again at $15,000 \times \mathrm{g}$ for $15 \mathrm{~min}$ at $4{ }^{\circ} \mathrm{C}$ and subjected to EPS-r and EPS-b extractions. The screening and extractions of EPS-r and EPS-b were carried out as described by Tallon et al. [62]. The final fractions were dried to constant weights. As a control, MRS broth without bacterial inoculum was used. The tests were conducted in triplicate. All the chemical compounds were supplied by Sigma-Aldrich (St. Louis, MO, USA).

\subsubsection{Antifungal Activity of EPSs}

The fractions of EPS-b and EPS-r, obtained from 20 mL of MRS medium, were rehydrated with $5 \mathrm{~mL}$ of physiological solution and added to $15 \mathrm{~mL}$ of MEA for antifungal activity tests against $A$. apis 3116 and $A$. apis 3117 using the same technique described in Section 2.3. The corresponding fractions of non-inoculated MRS medium were used as controls. The tests were conducted in triplicate.

\subsection{Antioxidant Activity}

\subsubsection{Bacterial Culture Matrices and Cell Protein Assay}

Overnight cultures $\left(10^{6} \mathrm{CFU} / \mathrm{mL}\right)$ of the L. plantarum strains in LM medium (Table S2) were centrifuged at $13,000 \mathrm{rpm}$ for $5 \mathrm{~min}$ at $4{ }^{\circ} \mathrm{C}$, and the obtained supernatants $\left(\mathrm{CFS}_{\mathrm{LM}}\right)$ were used directly for the antioxidant activity assay.

Cell pellets (CPs) were divided into two aliquots to determine their protein content and antioxidant activity. For total cell protein extraction, the $\mathrm{CP}$ was resuspended in $1 \mathrm{~mL}$ of Tris-buffered saline (TRIS) solution at $\mathrm{pH}$ 7.5; $20 \mathrm{mM}$ containing ethylenediaminetetraacetic acid (EDTA) $5 \mathrm{mM}$ and $\mathrm{MgCl}_{2} 5 \mathrm{mM}$, and then subjected to three cycles of sonication at $12 \mathrm{~W}$ for $30 \mathrm{~s}$, with a $60 \mathrm{~s}$ pause between the cycles, using a Labsonic M. The suspension was used for protein measurement according to Di Martino et al. [63] using a BioSpectrometer (Eppendorf, Hamburg, Germany). The total protein concentrations, expressed as $\mu \mathrm{g} / \mathrm{mL}$, were calculated by means of a calibration curve where bovine serum albumin (BSA) was used as a standard.

For antioxidant activity, the CP was washed twice with sterile water and resuspended in $200 \mu \mathrm{L}$ of ethanol/water (40/60). The cell pellet suspensions were sonicated (12 W for $30 \mathrm{~s}$, with a $60 \mathrm{~s}$ pause between the cycles) and, after $12 \mathrm{~h}$ of storage at $-20^{\circ} \mathrm{C}$, centrifuged at $13,000 \mathrm{rpm}$ for $15 \mathrm{~min}$ at $4{ }^{\circ} \mathrm{C}$. The supernatants (CES) were used for the evaluation of antioxidant activity. All the reagents used in this experiment were from Sigma-Aldrich (St. Louis, MO, USA). All the experiments were performed in triplicate.

\subsubsection{Antioxidant Activity Assay}

The total antioxidant activity (TAA) of the $\mathrm{CFS}_{\mathrm{LM}}$ and CES, obtained as described above, was evaluated using the 2,2 azino-bis 3-ethylbenzothiazoline-6-sulfonic acid (ABTS·+) radical cation method according to Re et al. [64], with some modifications. Briefly, ABTS was dissolved in water to a concentration of $7 \mathrm{mM}$. ABTS radical cations (ABTS-+) were produced by reacting the ABTS stock solution with $2.45 \mathrm{mM}$ potassium persulfate (final concentration) and allowing the mixture to stand in the dark at room temperature for $24 \mathrm{~h}$ before use. The ABTS + solution was diluted with citrate buffer ( $\mathrm{pH} 4.0$ ) to an optical density (OD) of 0.700 at $734 \mathrm{~nm}$. Then, $100 \mu \mathrm{L}$ of $\mathrm{CFS}_{\mathrm{LM}}$ and CES were mixed with $900 \mu \mathrm{L}$ of the ABTS + solution. The OD was measured at $734 \mathrm{~nm}$ after $4 \mathrm{~min}$ in the dark at room temperature using a BioSpectrometer (Eppendorf, Hamburg, Germany). Ascorbic acid was used as the standard for the calibration curve. The antioxidant activity of $\mathrm{CFS}_{\mathrm{LM}}$ was expressed as $\mu \mathrm{g}$ ascorbic acid/mL; the antioxidant activity of CES was expressed as the ratio $(w / w)$ between ascorbic acid (ng) and protein ( $\mu$ g; BSA equivalents). All the reagents used for this experiment were from Sigma-Aldrich (St. Louis, MO, USA). All the experiments were performed in triplicate. 


\subsection{Statistical Analysis}

All the data obtained from three independent experiments are expressed as mean \pm standard deviation (SD). Statistical analysis was performed using an analysis of variance (ANOVA) followed by Tukey's multiple comparison test. Statistical significance was attributed to $p$-values $<0.05$. SPSS software (IBM SPSS Statistics 21) was used for the analysis. The heatmap of biofilm production was generated using ClustVis web tool [65].

\section{Results}

\subsection{Antifungal Activity}

In a preliminary antifungal test, all $22 \mathrm{~L}$. plantarum strains showed antifungal activity but with different intensities (Table S1).

The L. plantarum strains LP8, LP25, LP86, LP95 and LP100 caused inhibition zones more than $2 \mathrm{~cm}$ in diameter and were selected for subsequent analysis.

In the anti-germinative tests, no significant differences were observed between the control (SG) and the samples containing the cultures (SGL) of the L. plantarum strains (Table S3).

The results of the inhibition of the radial mycelial growth of the A. apis 3116 and A. apis 3117 strains by the various matrices of $L$. plantarum cultures are summarized in Figure 1.

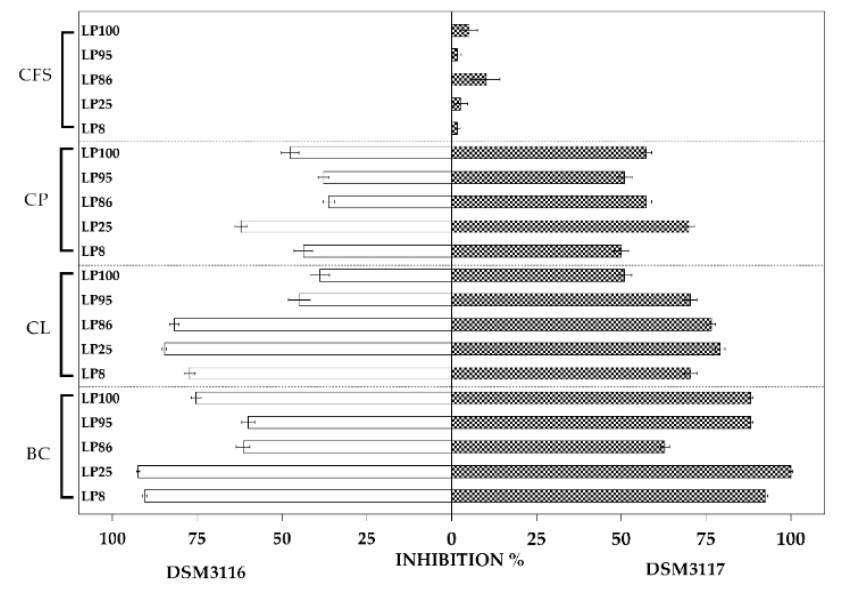

Figure 1. Inhibition (\%) of A. apis DSM 3116 and A. apis DSM 3117 (radial growth) on Malt Extract Agar (MEA) plates after 8 days using culture broth (CB), cell pellet (CP), cell-free supernatant (CFS) and cell lysate (CL) from the L. plantarum strains.

The results of the various tests show that there were significant differences between the radial growth percentage values obtained using different matrices. The numerical data are reported in Table S4.

After 8 days, the L. plantarum broth cultures (BCs) caused greater inhibition of the two fungi than the other matrices did, with values between $60.0 \%$ (LP95) and $92.4 \%$ (LP25) against $A$. apis 3116, and $62.9 \%$ (LP86) and 100\% (LP25) against $A$. apis 3117 .

The cell lysates (CLs) inhibited the fungi more than the CP and CFS matrices. In particular, they caused inhibition rates between $38.8 \%$ (LP100) and $84.8 \%$ (LP25) for A. apis 3116, and between $50.9 \%$ (LP100) and 79.2\% (LP25) for A. apis 3117. The cell pellets (CPs) showed inhibitory activity ranging from $36.3 \%$ (LP86) to $62.1 \%$ (LP25) against $A$. apis 3116, and from $50.0 \%$ (LP8) and $69.8 \%$ (LP25) against A. apis 3117. The cell-free supernatants (CFSs), overall, showed less inhibitory activity, which was found to be between $1.7 \%$ (LP8 and LP95) and 10.2\% (LP86) for A. apis 3117, and they did not inhibit A. apis 3116. Figure 2 shows the inhibitory activity of L. plantarum LP25 against A. apis DSM 3117 after 8 days on MEA agar plates. EPS-b and EPS-r did not inhibit A. apis 3116 or A. apis 3117. 


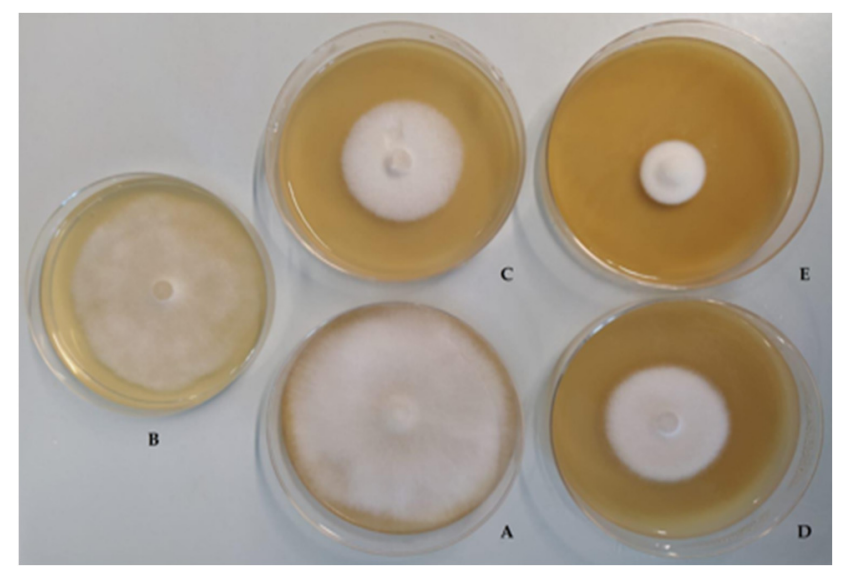

Figure 2. Inhibitory activity of L. plantarum LP100 against A. apis DSM 3116 after 8 days on MEA agar plates. A: A. apis (control); B: A. apis + CFS (cell-free supernatant); C: A. apis + CL (cell lysate); D: A. apis + CP (cell pellet); E: A. apis + BC (broth culture).

\subsection{EPS and Biofilm Production}

The amounts of EPS produced by the five L. plantarum strains are reported in Table 1 . The EPS-r values, expressed as $\mathrm{mg} / \mathrm{mL}$, were obtained for each bacterial culture $\left(10^{8} \mathrm{CFU} / \mathrm{mL}\right)$ in MRS broth. The EPS- $b$ values are expressed as the ratio between EPS-b $(\mu \mathrm{g})$ and cell protein ( $\mu \mathrm{g}$, BSA equivalents) obtained for each bacterial culture $\left(10^{8} \mathrm{CFU} / \mathrm{mL}\right)$ in MRS broth. The data show statistically significant differences $(p<0.05)$. The EPS-r values were between 0.82 (LP95) and $1.56 \mathrm{mg} / \mathrm{mL}$ (LP25), while the EPS-b values were between 1.96 (LP95) and $8.82 \mathrm{mg} / \mathrm{mL}$ (LP8).

Table 1. EPS production in MRS medium after $48 \mathrm{~h}$ and antioxidant activity in LM medium of L. plantarum LP8, LP25, LP86, LP95 and LP100 strains. All values are expressed as mean \pm standard deviation $(n=3)$. Different lowercase letters $(a-d)$ in each row indicate significant differences $(p<0.05)$.

\begin{tabular}{|c|c|c|c|c|c|}
\hline & \multicolumn{5}{|c|}{ L. plantarum Strains } \\
\hline & LP8 & LP25 & LP86 & LP95 & LP100 \\
\hline $\mathrm{CFS}_{\mathrm{LM}}$ & \multirow{2}{*}{$37.45 \pm 0.40^{c}$} & \multirow{2}{*}{$36.88 \pm 0.40^{c}$} & \multirow{2}{*}{$25.73 \pm 0.81^{b}$} & \multirow{2}{*}{$22.30 \pm 0.05^{\mathrm{a}}$} & \multirow{2}{*}{$20.01 \pm 0.81$} \\
\hline antioxidant activity * & & & & & \\
\hline CES * & \multirow{2}{*}{$0.17 \pm 0.02^{b}$} & \multirow{2}{*}{$0.16 \pm 0.01^{\mathrm{b}}$} & \multirow{2}{*}{$0.12 \pm 0.01^{\mathrm{a}}$} & \multirow{2}{*}{$0.14 \pm 0.01^{\mathrm{a}}$} & \multirow{2}{*}{$0.11 \pm 0.00^{\mathrm{a}}$} \\
\hline antioxidant activity ** & & & & & \\
\hline EPS-r & $1.40 \pm 0.03^{b}$ & $1.56 \pm 0.50^{c}$ & $1.28 \pm 0.10^{b}$ & $0.82 \pm 0.07^{\mathrm{a}}$ & $1.49 \pm 0.06^{b}$ \\
\hline EPS-b & $8.82 \pm 0.11^{\mathrm{d}}$ & $2.23 \pm 0.09^{a}$ & $5.05 \pm 0.12^{b}$ & $1.96 \pm 0.08^{a}$ & $5.54 \pm 0.10^{c}$ \\
\hline
\end{tabular}

${ }^{*} \mathrm{CFS}_{\mathrm{LM}}$ antioxidant activity expressed as ascorbic acid $(\mathrm{ng}) / \mathrm{mL} ;{ }^{* *} \mathrm{CES}$ antioxidant activity expressed as ratio of ascorbic acid $(\mu \mathrm{g}) / \mathrm{cell}$ protein ( $\mu \mathrm{g}$ BSA equivalents); EPS-r values expressed as $\mathrm{mg} / \mathrm{mL}$; EPS-b values expressed as the ratio of EPS-b $(\mu \mathrm{g}) /$ cell protein $(\mu \mathrm{g}$ BSA equivalents).

Figure 3 shows a heatmap in which the L. plantarum strains are clustered based on their different capacities to form biofilms in different media and environmental conditions. The biofilms were assessed by measuring the optical density (OD), and the numerical data are shown in Table S5. All the tested L. plantarum strains were able to produce biofilms in all the conditions, but to different degrees, depending on the concentration and type of the added sugar. L. plantarum LP8 produced, under all the conditions, greater amounts of biofilm than the other strains. 


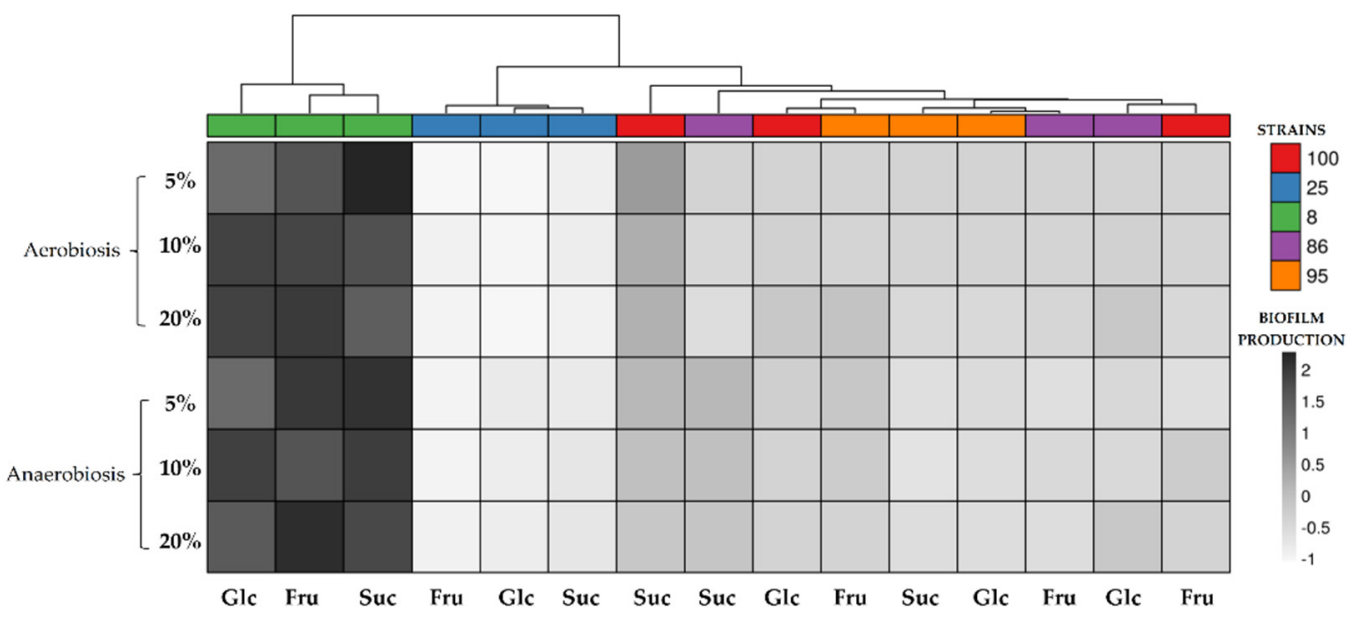

Figure 3. Biofilm production of L. plantarum LP8, LP25, LP86, LP95 and LP100 strains in aerobiotic and anaerobiotic conditions and with different sugar concentrations (5\%,10\% and 20\% (Glc: glucose; Fru: fructose; Suc: sucrose)). This figure was generated using ClustVis web tool [65] https:/ / biit.cs.ut.ee/clustvis/ (accessed on 4 December 2020).

In all the tests, the anaerobiotic condition almost always favored the production of biofilms. In particular, the L. plantarum LP8 strain always produced more biofilm than the other strains under this condition. The anaerobiotic condition favored biofilm production in the tests with both glucose and sucrose for the LP25 strain, in the sucrose tests for the LP86 strain and in the fructose tests for the LP95 and LP100 strains.

All the bacterial strains tended to produce increasing amounts of biofilm as the sugar concentration increased, although there were often no significant differences $(p>0.05)$. Once again, the LP8 strain stood out because it produced increasing amounts of biofilm under the conditions of greater osmolarity of the sugar syrup; the differences for this strain were almost always significant $(p<0.05)$, except in the test conducted under aerobiosis with the addition of sucrose.

\subsection{Antioxidant Activity}

The antioxidant activities of the $\mathrm{CFS}_{\mathrm{LM}}$ and CES matrices are shown in Table 1. The $L$. plantarum strains produced different results for each of the two matrices. The antioxidant activity values of the $\mathrm{CFS}_{\mathrm{LM}}$, expressed as ng of ascorbic acid $/ \mathrm{mL}$, were between 20.01 (LP100) and 37.45 (LP8). Those of the CES, expressed as the ratio between ascorbic acid $(\mu \mathrm{g})$ and cell protein ( $\mu \mathrm{g}$ BSA equivalents), were between 0.11 (LP100) and 0.17 (LP8).

\section{Discussion}

\subsection{Antifungal Activity}

Our purpose was to investigate the ability of L. plantarum to inhibit two different $A$. apis strains, DSM 3116 and DSM 3117. The results suggest that sensitivity to the bacterial cultures may be species- and not strain-dependent. Future in vivo tests will be performed to verify the antifungal activity of L. plantarum against wild A. apis strains.

Our study demonstrated that the L. plantarum strains did not affect the germination capacity of fungal spores, while these LAB exhibited the ability to inhibit the vegetative form of A. apis in vitro. The mycelial hyphae of this fungus, which are responsible for its virulent action, penetrate the peritrophic membrane and gut wall barrier to enter the honeybee hemocoel. The pressure caused by the septate hyphae and the enzymatic activity favor access to the interstitial space between the muscle fibers of infected larvae [66,67]. The epithelial cells of the larval gastrointestinal tract are protected from pathogen colonization by several mechanisms exerted by commensal microbiota, including competition for adhesion sites or nutrient sources and producing antimicrobial substances [51,52,68,69].

Many other researchers have shown that the antimicrobial activity of LAB is primarily attributed to the CFS, in which several antimicrobial compounds are found, including 
organic acids (lactic, acetic, formic, propionic, butyric, hydroxylphenylactic and phenylactic acids) and other inhibitory substances (e.g., carbon dioxide, hydroperoxide, fatty acids and bacteriocins) [70-82].

Our tests of A. apis inhibition demonstrated that all five L. plantarum strains had strong antifungal activity. High inhibition occurred with the use of the broth cultures (BC), which was most likely due to an interaction between several factors. In addition, the inhibitory effects obtained using the cell pellet $(\mathrm{CP})$ and cell lysate $(\mathrm{CL})$ were stronger than those obtained with the cell-free supernatant (CFS). Our results suggest that there may be synergy between various compounds, extra- and intracellular, that substantially increases the overall antifungal activity. This has also been hypothesized by other researchers [51-56,59-64,68-78]. Our tests showed that the EPS-b and EPS-r fractions did not inhibit A. apis 3116 and A. apis 3117. This suggests that the higher inhibitory effect of the CL compared to the CFS was probably due to the release of antifungal compounds from the bacterial cytoplasm after cell lysis.

The mechanisms behind the inhibition may involve some individual compounds that can cause membrane destabilization (such as fatty acids or peptides), proton gradient interference (such as organic acids or peptides) or enzyme inhibition (such as hydroxy acids). In addition, there may be some synergistic and/or additive effects involving various compounds [83].

The antifungal compounds contained in the $\mathrm{BC}$ and $\mathrm{CL}$ matrices need to be investigated in future research, and after their identification and purification, we plan to use them in anti-germination tests on $A$. apis spores.

The antifungal properties of the L. plantarum strains shown in vitro do not axiomatically result in health benefits for honeybee colonies. It is therefore necessary to assess the role that these bacteria play in maintaining honeybee wellbeing and the contribution they can provide for the biological control of chalkbrood disease. In particular, we are testing the effects of sugar syrups enriched with lysates or live and active cultures of these L. plantarum strains, added to the diets of honeybee colonies in vivo/in situ.

\subsection{EPS and Biofilm Production}

Our results show that these five L. plantarum strains are able to produce EPSs and biofilms. As a result, these bacteria can persist in the intestine, where there is an abundant flow of sugars, enzymes and water and the constant invasion of foreign microbes following the ingestion of flower nectar during foraging [15,84-91]. The germination of $A$. apis spores occurs in the midgut lumens of infected honeybee larvae. The hyphae penetrate the peritrophic membrane and gut epithelium, and then invade larval tissues [3]. The inhibition of A. apis mycelial growth is an important key step for preventing the colonization of the intestinal cavity. Adhesion to the intestinal wall and the formation of biofilms by probiotic bacterial antagonists of pathogenic fungi could constitute an obstacle to the development and consequent invasive action of fungal mycelia.

Our tests also confirmed that EPS and biofilm production are strain-dependent, as documented by other researchers [92]. L. plantarum LP8 produced the largest quantities of EPS-b and biofilm, demonstrating that exopolysaccharides linked to the bacterial wall are important in the composition and architecture of biofilms [93-95].

The formation of EPSs and the development of a biofilm are also affected by other factors, including surface properties and environmental parameters [96-98]. Our results show that anaerobiotic conditions and increased osmolarity often significantly favor biofilm production (Table S5). This suggests that the microaerophilic/anaerobic conditions of the intestinal tract can favor the production of biofilms and the resulting intestinal colonization by these bacteria.

In the future, it will be necessary to perform this test with cell lines to confirm the adhesion of the five selected L. plantarum strains to the epithelial cells. 


\subsection{Antioxidant Activity}

Oxidative stress is important in eukaryotic organisms and can cause severe negative effects. Reactive oxygen species (ROS) are the causative agents of oxidative stress, and they are produced during normal metabolic processes. Insects have a range of antioxidant enzymes, mainly composed of superoxide dismutase (SOD), catalase (CAT) and peroxidase (POD). Glutathione peroxidase (GPX) and glutathione reductase (GSR) can also remove ROS [99-101].

Detoxification enzymes play a critical, crucial role in honeybees exposed to biotic and abiotic stressors through ecological interactions with their environments (nutritional and thermal stress, parasites, heavy metals and/or pesticides) [102-110]. Oxidative stress has been reported to play an important pathological role in honeybee diseases. Even during the excessive proliferation of pathogens, the intestinal epithelium produces and releases high levels of ROS, causing significant oxidative stress [111-113]. Li et al. [4] recently reported that $A$. apis infection induced oxidative stress in honeybee larvae, and decreased levels of the metabolites involved in combating oxidative stress could compromise the antioxidant defenses of the infected larvae. The specific activities of antioxidant enzymes (CAT, GST and SOD) and the levels of metabolites (taurine, docosahexaenoic acid and L-carnitine) involved in combating oxidative stress were significantly decreased in the guts of infected honeybee larvae.

Increased attention has been paid over the last decade to the use of LAB as natural antioxidants. Some LAB strains have enzymatic and nonenzymatic antioxidant activity and promote the production of antioxidant enzymes, decreasing the risk of ROS accumulation during the ingestion of food, thereby reducing oxidative damage [114-118].

We assessed antioxidant activity using the ABTS assay, which is considered one of the most sensitive techniques [119] and a valid method for determining the antioxidant activity of both hydrophilic and lipophilic extracts [120]. All five L. plantarum strains showed antioxidant activity in the $\mathrm{CFS}_{\mathrm{LM}}$ and CES matrices, and this suggests that their antioxidant activities may be due to different substances (e.g., intracellular antioxidant enzymes, nonenzymatic antioxidant components such as glutathione, cell surface proteins or polysaccharides, etc.), which need to be investigated in greater detail.

These bacteria, if used as probiotics in the diets of honeybees, could limit oxidative stress due to pathogenic $A$. apis fungi and other biotic and abiotic factors.

\section{Conclusions}

The L. plantarum strains used in our experiments have been shown to possess substances biologically active against $A$. apis fungi. These results confirm the potentially antagonistic role of L. plantarum against pathogenic microorganisms that use the digestive channels of honeybees as the sites of infection [47]. Moreover, our findings indicate the ability of the L. plantarum LP8, LP25, LP86, LP95 and LP100 strains to produce EPSs and form biofilms, which are prerequisites for potential candidates to be used as probiotics in the honeybee diet. In addition, the antioxidant properties of the tested bacterial strains can help to increase the tolerance of these insects to endogenous and exogenous oxidative stress. The obtained results encourage the design of strategies to improve honeybee health through nutritional approaches or the modulation of the gut microbiota using beneficial microbes and open up a new horizon for fighting honeybee pathogens.

Future research activities will involve the investigation of the nature of the antifungal compounds and evaluate the effects of these L. plantarum strains on honeybee health and productivity, and their efficacy in chalkbrood disease biocontrol in vivo/in situ.

Supplementary Materials: The following are available online at https: / www.mdpi.com/article / 10.3390/jof7050379/s1. Table S1: List of 22 L. plantarum strains, Table S2: Letizia medium (LM) composition, Table S3: Spore germination, Table S4: Fungal inhibition, Table S5: Biofilm production.

Author Contributions: Conceptualization, M.I. (Massimo Iorizzo) and R.C.; data curation, M.S., P.T. and E.S.; formal analysis, M.I. (Mario Ianiro), B.T., S.J.L., S.G., S.P., F.V. and A.C.; funding acquisition, 
R.C.; investigation, B.T., S.P. and P.T.; methodology, S.J.L., S.G., B.T., F.V. and A.C.; project administration, S.P.; resources, R.C. and A.D.C.; software, F.L.; supervision, R.C. and A.D.C.; validation, M.S.; writing-original draft, S.G. and M.I. (Massimo Iorizzo); writing—review and editing, M.I. (Massimo Iorizzo), S.G. and F.L. Authorship must be limited to those who have contributed substantially to the work reported. All authors have read and agreed to the published version of the manuscript.

Funding: This research received no external funding.

Institutional Review Board Statement: Not applicable.

Informed Consent Statement: Not applicable.

Data Availability Statement: Not applicable.

Conflicts of Interest: The authors declare no conflict of interest.

\section{References}

1. Evison, S.E.; Jensen, A.B. The Biology and Prevalence of Fungal Diseases in Managed and Wild Bees. Ecol. Parasites Parasit. Biol. Control 2018, 26, 105-113. [CrossRef]

2. Evison, S.E. Chalkbrood: Epidemiological Perspectives from the Host-Parasite Relationship. Soc. Insects Vectors Med. Vet. Entomol. 2015, 10, 65-70. [CrossRef] [PubMed]

3. Aronstein, K.A.; Murray, K.D. Chalkbrood Disease in Honey Bees. J. Invertebr. Pathol. 2010, 103, S20-S29. [CrossRef] [PubMed]

4. Li, Z.; Hou, M.; Qiu, Y.; Zhao, B.; Nie, H.; Su, S. Changes in Antioxidant Enzymes Activity and Metabolomic Profiles in the Guts of Honey Bee (Apis Mellifera) Larvae Infected with Ascosphaera Apis. Insects 2020, 11, 419. [CrossRef]

5. Bamford, S.; Heath, L.A.F. The Effects of Temperature and PH on the Germination of Spores of the Chalkbrood Fungus, Ascosphaera Apis. J. Apic. Res. 1989, 28, 36-40. [CrossRef]

6. Bailey, L.; Ball, B.V. (Eds.) 5-FUNGI. In Honey Bee Pathology, 2nd ed.; Academic Press: London, UK, 1991 ; pp. 53-63. ISBN 978-0-12-073481-8.

7. Spivak, M.; Reuter, G.S. Performance of Hygienic Honey Bee Colonies in a Commercial Apiary. Apidologie 1998, 29, 291-302. [CrossRef]

8. Invernizzi, C.; Rivas, F.; Bettucci, L. Resistance to Chalkbrood Disease in Apis Mellifera L. (Hymenoptera: Apidae) Colonies with Different Hygienic Behaviour. Neotrop. Entomol. 2011, 40, 28-34. [CrossRef]

9. Manley, R.; Boots, M.; Wilfert, L. REVIEW: Emerging Viral Disease Risk to Pollinating Insects: Ecological, Evolutionary and Anthropogenic Factors. J. Appl. Ecol. 2015, 52, 331-340. [CrossRef]

10. Castagnino, G.L.B.; Mateos, A.; Meana, A.; Montejo, L.; Zamorano Iturralde, L.V.; Cutuli de Simón, M.T. Etiology, Symptoms and Prevention of Chalkbrood Disease: A Literature Review. Rev. Bras. Saúde E Produção Anim. 2020, 21. [CrossRef]

11. Engel, P.; Moran, N.A. Functional and Evolutionary Insights into the Simple yet Specific Gut Microbiota of the Honey Bee from Metagenomic Analysis. Gut Microbes 2013, 4, 60-65. [CrossRef]

12. Cox-Foster, D.L.; Conlan, S.; Holmes, E.C.; Palacios, G.; Evans, J.D.; Moran, N.A.; Quan, P.-L.; Briese, T.; Hornig, M.; Geiser, D.M.; et al. A Metagenomic Survey of Microbes in Honey Bee Colony Collapse Disorder. Science 2007, 318, 283. [CrossRef] [PubMed]

13. Hamdi, C.; Balloi, A.; Essanaa, J.; Crotti, E.; Gonella, E.; Raddadi, N.; Ricci, I.; Boudabous, A.; Borin, S.; Manino, A.; et al. Gut Microbiome Dysbiosis and Honeybee Health. J. Appl. Entomol. 2011, 135, 524-533. [CrossRef]

14. Alberoni, D.; Gaggìa, F.; Baffoni, L.; Di Gioia, D. Beneficial Microorganisms for Honey Bees: Problems and Progresses. Appl. Microbiol. Biotechnol. 2016, 100, 9469-9482. [CrossRef]

15. Raymann, K.; Moran, N.A. The Role of the Gut Microbiome in Health and Disease of Adult Honey Bee Workers. Ecol. Parasites Parasit. Biol. Control 2018, 26, 97-104. [CrossRef] [PubMed]

16. Sabaté, D.C.; Carrillo, L.; Carina Audisio, M. Inhibition of Paenibacillus Larvae and Ascosphaera Apis by Bacillus Subtilis Isolated from Honeybee Gut and Honey Samples. Res. Microbiol. 2009, 160, 193-199. [CrossRef]

17. Li, J.; Zheng, Z.; Hong, S.; Qi, X.; Liang, Q. Isolation and Identification of an Antagonistic Bacterial Strain against Ascosphaera Apis from Honeybee Larvae Infected with Chalkbrood Disease. Sci. Agric. Sin. 2012, 45, 973-980.

18. Omar, M.O.M.; Moustafa, A.M.; Ansari, M.J.; Anwar, A.M.; Fahmy, B.F.; Al-Ghamdi, A.; Nuru, A. Antagonistic Effect of Gut Bacteria in the Hybrid Carniolan Honey Bee, Apis Mellifera Carnica, Against Ascosphaera Apis, the Causal Organism of Chalkbrood Disease. J. Apic. Sci. 2014, 58, 17-27. [CrossRef]

19. Heath, L.A.F. Development of Chalk Brood in a Honeybee Colony: A Review. Bee World 1982, 63, 119-130. [CrossRef]

20. Liu, T.P. Ultrastructural Changes in the Spore and Mycelia of Ascosphaera Apis after Treatment with Benomyl (Benlate 50 W). Mycopathologia 1991, 116, 23-28. [CrossRef]

21. Glinski, Z.; Chmielewski, M. Imidazole Derivatives in Control of the Honey Bee Brood Mycoses. Pszczel. Zesz. Nauk. Pol. 1996, 40, 165-173.

22. Davis, C. Control of Chalkbrood Disease with Natural Products: A Report for the Rural Industries Research and Development Corporation/by Craig Davis and Wendy Ward; RIRDC Publication; No. 03/107; Rural Industries Research and Development Corporation: Barton, ACT, Austrilia, 2003. 
23. Frazier, M.; Mullin, C.; Frazier, J.; Ashcraft, S. What Have Pesticides Got to Do with It? Am. Bee J. 2008, 148, 521-524.

24. Gaggia, F.; Baffoni, L.; Alberoni, D. Probiotics for honeybees' health. In Probiotics and Prebiotics in Animal Health and Food Safety; Springer: Berlin/Heidelberg, Germany, 2018; pp. 219-245.

25. Al-Ghamdi, A.; Ali Khan, K.; Javed Ansari, M.; Almasaudi, S.B.; Al-Kahtani, S. Effect of Gut Bacterial Isolates from Apis Mellifera Jemenitica on Paenibacillus Larvae Infected Bee Larvae. Saudi J. Biol. Sci. 2018, 25, 383-387. [CrossRef]

26. Tejerina, M.R.; Benítez-Ahrendts, M.R.; Audisio, M.C. Lactobacillus Salivarius A3iob Reduces the Incidence of Varroa Destructor and Nosema Spp. in Commercial Apiaries Located in the Northwest of Argentina. Probiotics Antimicrob. Proteins 2020, 12, 1360-1369. [CrossRef]

27. Daisley, B.A.; Pitek, A.P.; Chmiel, J.A.; Al, K.F.; Chernyshova, A.M.; Faragalla, K.M.; Burton, J.P.; Thompson, G.J.; Reid, G. Novel Probiotic Approach to Counter Paenibacillus Larvae Infection in Honey Bees. ISME J. 2020, 14, 476-491. [CrossRef]

28. Ramos, O.Y.; Basualdo, M.; Libonatti, C.; Vega, M.F. Current Status and Application of Lactic Acid Bacteria in Animal Production Systems with a Focus on Bacteria from Honey Bee Colonies. J. Appl. Microbiol. 2020, 128, 1248-1260. [CrossRef]

29. Tejerina, M.R.; Cabana, M.J.; Benitez-Ahrendts, M.R. Strains of Lactobacillus Spp. Reduce Chalkbrood in Apis Mellifera. J. Invertebr. Pathol. 2021, 178, 107521. [CrossRef]

30. Zheng, J.; Wittouck, S.; Salvetti, E.; Franz, C.M.; Harris, H.M.; Mattarelli, P.; O’Toole, P.W.; Pot, B.; Vandamme, P.; Walter, J. A Taxonomic Note on the Genus Lactobacillus: Description of 23 Novel Genera, Emended Description of the Genus Lactobacillus Beijerinck 1901, and Union of Lactobacillaceae and Leuconostocaceae. Int. J. Syst. Evol. Microbiol. 2020, 70, 2782-2858. [CrossRef]

31. Van Hoorde, K.; Verstraete, T.; Vandamme, P.; Huys, G. Diversity of Lactic Acid Bacteria in Two Flemish Artisan Raw Milk Gouda-Type Cheeses. Food Microbiol. 2008, 25, 929-935. [CrossRef]

32. Wouters, D.; Grosu-Tudor, S.; Zamfir, M.; De Vuyst, L. Bacterial Community Dynamics, Lactic Acid Bacteria Species Diversity and Metabolite Kinetics of Traditional Romanian Vegetable Fermentations. J. Sci. Food Agric. 2013, 93, 749-760. [CrossRef]

33. Gotteland, M.; Cires, M.J.; Carvallo, C.; Vega, N.; Ramirez, M.A.; Morales, P.; Rivas, P.; Astudillo, F.; Navarrete, P.; Dubos, C.; et al. Probiotic Screening and Safety Evaluation of Lactobacillus Strains from Plants, Artisanal Goat Cheese, Human Stools, and Breast Milk. J. Med. Food 2014, 17, 487-495. [CrossRef]

34. Tajabadi, N.; Mardan, M.; Saari, N.; Mustafa, S.; Bahreini, R.; Manap, M.Y.A. Identification of Lactobacillus Plantarum, Lactobacillus Pentosus and Lactobacillus Fermentum from Honey Stomach of Honeybee. Braz. J. Microbiol. Publ. Braz. Soc. Microbiol. 2014, 44, 717-722. [CrossRef]

35. Javorský, P.; Fecskeová, L.K.; Hrehová, L.; Sabo, R.; Legáth, J.; Pristas, P. Establishment of Lactobacillus Plantarum Strain in Honey Bee Digestive Tract Monitored Using Gfp Fluorescence. Benef. Microbes 2017, 8, 291-297. [CrossRef] [PubMed]

36. Parichehreh, S.; Tahmasbi, G.; Sarafrazi, A.; Imani, S.; Tajabadi, N. Isolation and Identification of Lactobacillus Bacteria Found in the Gastrointestinal Tract of the Dwarf Honey Bee, Apis Florea Fabricius, 1973 (Hymenoptera: Apidae). Apidologie 2018, 49, 430-438. [CrossRef]

37. Iorizzo, M.; Pannella, G.; Lombardi, S.J.; Ganassi, S.; Testa, B.; Succi, M.; Sorrentino, E.; Petrarca, S.; De Cristofaro, A.; Coppola, R.; et al. Inter- and Intra-Species Diversity of Lactic Acid Bacteria in Apis Mellifera Ligustica Colonies. Microorganisms 2020, 8, 1578. [CrossRef] [PubMed]

38. Corby-Harris, V.; Pontaroli, A.C.; Shimkets, L.J.; Bennetzen, J.L.; Habel, K.E.; Promislow, D.E.L. Geographical Distribution and Diversity of Bacteria Associated with Natural Populations of Drosophila Melanogaster. Appl. Environ. Microbiol. 2007, 73, 3470. [CrossRef] [PubMed]

39. Ren, C.; Webster, P.; Finkel, S.E.; Tower, J. Increased Internal and External Bacterial Load during Drosophila Aging without Life-Span Trade-Off. Cell Metab. 2007, 6, 144-152. [CrossRef] [PubMed]

40. Ryu, J.-H.; Kim, S.-H.; Lee, H.-Y.; Bai, J.Y.; Nam, Y.-D.; Bae, J.-W.; Lee, D.G.; Shin, S.C.; Ha, E.-M.; Lee, W.-J. Innate Immune Homeostasis by the Homeobox Gene Caudal and Commensal-Gut Mutualism in Drosophila. Science 2008, 319, 777. [CrossRef]

41. Sharon, G.; Segal, D.; Ringo, J.M.; Hefetz, A.; Zilber-Rosenberg, I.; Rosenberg, E. Commensal Bacteria Play a Role in Mating Preference of Drosophila Melanogaster. Proc. Natl. Acad. Sci. USA 2010, 107, 20051. [CrossRef]

42. Storelli, G.; Defaye, A.; Erkosar, B.; Hols, P.; Royet, J.; Leulier, F. Lactobacillus Plantarum Promotes Drosophila Systemic Growth by Modulating Hormonal Signals through TOR-Dependent Nutrient Sensing. Cell Metab. 2011, 14, 403-414. [CrossRef] [PubMed]

43. Niku-Paavola, M.-L.; Laitila, A.; Mattila-Sandholm, T.; Haikara, A. New Types of Antimicrobial Compounds Produced by Lactobacillus Plantarum. J. Appl. Microbiol. 1999, 86, 29-35. [CrossRef]

44. Lavermicocca, P.; Valerio, F.; Evidente, A.; Lazzaroni, S.; Corsetti, A.; Gobbetti, M. Purification and Characterization of Novel Antifungal Compounds from the Sourdough Lactobacillus Plantarum Strain 21B. Appl. Environ. Microbiol. 2000, 66, 4084. [CrossRef] [PubMed]

45. Sjögren, J.; Magnusson, J.; Broberg, A.; Schnürer, J.; Kenne, L. Antifungal 3-Hydroxy Fatty Acids from Lactobacillus Plantarum MiLAB 14. Appl. Environ. Microbiol. 2003, 69, 7554. [CrossRef] [PubMed]

46. Barbosa, M.S.; Todorov, S.D.; Ivanova, I.V.; Belguesmia, Y.; Choiset, Y.; Rabesona, H.; Chobert, J.-M.; Haertlé, T.; Franco, B.D.G.M. Characterization of a Two-Peptide Plantaricin Produced by Lactobacillus Plantarum MBSa4 Isolated from Brazilian Salami. Food Control 2016, 60, 103-112. [CrossRef]

47. Iorizzo, M.; Testa, B.; Lombardi, S.J.; Ganassi, S.; Ianiro, M.; Letizia, F.; Succi, M.; Tremonte, P.; Vergalito, F.; Cozzolino, A.; et al. Antimicrobial Activity against Paenibacillus Larvae and Functional Properties of Lactiplantibacillus Plantarum Strains: Potential Benefits for Honeybee Health. Antibiotics 2020, 9, 442. [CrossRef] [PubMed] 
48. Behera, S.S.; Ray, R.C.; Zdolec, N. Lactobacillus Plantarum with Functional Properties: An Approach to Increase Safety and Shelf-Life of Fermented Foods. BioMed Res. Int. 2018, 2018, 9361614. [CrossRef] [PubMed]

49. Seddik, H.A.; Bendali, F.; Gancel, F.; Fliss, I.; Spano, G.; Drider, D. Lactobacillus Plantarum and Its Probiotic and Food Potentialities. Probiotics Antimicrob. Proteins 2017, 9, 111-122. [CrossRef]

50. Royan, M. Mechanisms of Probiotic Action in the Honeybee. Crit. Rev. Eukaryot. Gene Expr. 2019, 29, 95-103. [CrossRef]

51. Deng, Z.; Luo, X.M.; Liu, J.; Wang, H. Quorum Sensing, Biofilm, and Intestinal Mucosal Barrier: Involvement the Role of Probiotic. Front. Cell. Infect. Microbiol. 2020, 10, 504. [CrossRef]

52. Bäumler, A.J.; Sperandio, V. Interactions between the Microbiota and Pathogenic Bacteria in the Gut. Nature 2016, 535, 85-93. [CrossRef]

53. Barzegari, A.; Kheyrolahzadeh, K.; Hosseiniyan Khatibi, S.M.; Sharifi, S.; Memar, M.Y.; Zununi Vahed, S. The Battle of Probiotics and Their Derivatives Against Biofilms. Infect. Drug Resist. 2020, 13, 659-672. [CrossRef]

54. Vu, B.; Chen, M.; Crawford, R.J.; Ivanova, E.P. Bacterial Extracellular Polysaccharides Involved in Biofilm Formation. Molecules 2009, 14, 535. [CrossRef]

55. Magnusson, J.; Ström, K.; Roos, S.; Sjögren, J.; Schnürer, J. Broad and Complex Antifungal Activity among Environmental Isolates of Lactic Acid Bacteria. FEMS Microbiol. Lett. 2003, 219, 129-135. [CrossRef]

56. Testa, B.; Lombardi, S.J.; Macciola, E.; Succi, M.; Tremonte, P.; Iorizzo, M. Efficacy of Olive Leaf Extract (Olea Europaea L. Cv Gentile Di Larino) in Marinated Anchovies (Engraulis Encrasicolus, L.) Process. Heliyon 2019, 5. [CrossRef] [PubMed]

57. Jensen, A.B.; Aronstein, K.; Flores, J.M.; Vojvodic, S.; Palacio, M.A.; Spivak, M. Standard Methods for Fungal Brood Disease Research. J. Apic. Res. 2013, 52. [CrossRef] [PubMed]

58. Heath, L.A.F.; Gaze, B.M. Carbon Dioxide Activation of Spores of the Chalkbrood Fungus Ascosphaera Apis. J. Apic. Res. 1987, 26, 243-246. [CrossRef]

59. Iorizzo, M.; Lombardi, S.J.; Ganassi, S.; Testa, B.; Ianiro, M.; Letizia, F.; Succi, M.; Tremonte, P.; Vergalito, F.; Cozzolino, A.; et al. Antagonistic Activity against Ascosphaera Apis and Functional Properties of Lactobacillus Kunkeei Strains. Antibiotics 2020, 9, 262. [CrossRef] [PubMed]

60. Ricci, A.; Levante, A.; Cirlini, M.; Calani, L.; Bernini, V.; Del Rio, D.; Galaverna, G.; Neviani, E.; Lazzi, C. The Influence of Viable Cells and Cell-Free Extracts of Lactobacillus Casei on Volatile Compounds and Polyphenolic Profile of Elderberry Juice. Front. Microbiol. 2018, 9, 2784. [CrossRef]

61. Cozzolino, A.; Vergalito, F.; Tremonte, P.; Iorizzo, M.; Lombardi, S.J.; Sorrentino, E.; Luongo, D.; Coppola, R.; Di Marco, R.; Succi, M. Preliminary Evaluation of the Safety and Probiotic Potential of Akkermansia Muciniphila DSM 22959 in Comparison with Lactobacillus Rhamnosus GG. Microorganisms 2020, 8, 189. [CrossRef]

62. Tallon, R.; Bressollier, P.; Urdaci, M.C. Isolation and Characterization of Two Exopolysaccharides Produced by Lactobacillus Plantarum EP56. Res. Microbiol. 2003, 154, 705-712. [CrossRef]

63. Di Martino, C.; Testa, B.; Letizia, F.; Iorizzo, M.; Lombardi, S.J.; Ianiro, M.; Di Renzo, M.; Strollo, D.; Coppola, R. Effect of Exogenous Proline on the Ethanolic Tolerance and Malolactic Performance of Oenococcus Oeni. J. Food Sci. Technol. 2020, 57, 3973-3979. [CrossRef]

64. Re, R.; Pellegrini, N.; Proteggente, A.; Pannala, A.; Yang, M.; Rice-Evans, C. Antioxidant Activity Applying an Improved ABTS Radical Cation Decolorization Assay. Free Radic. Biol. Med. 1999, 26, 1231-1237. [CrossRef]

65. Metsalu, T.; Vilo, J. ClustVis: A Web Tool for Visualizing Clustering of Multivariate Data Using Principal Component Analysis and Heatmap. Nucleic Acids Res. 2015, 43, W566-W570. [CrossRef]

66. Albo, G.N.; Cordoba, S.B.; Reynaldi, F.J. Chalkbrood: Pathogenesis and the Interaction with Honeybee Defenses. Int. J. Environ. Agric. Res. 2017, 3, 71-80.

67. Maxfield-Taylor, S.A.; Mujic, A.B.; Rao, S. First Detection of the Larval Chalkbrood Disease Pathogen Ascosphaera Apis (Ascomycota: Eurotiomycetes: Ascosphaerales) in Adult Bumble Bees. PLoS ONE 2015, 10, e0124868. [CrossRef] [PubMed]

68. Landini, P.; Antoniani, D.; Burgess, J.G.; Nijland, R. Molecular Mechanisms of Compounds Affecting Bacterial Biofilm Formation and Dispersal. Appl. Microbiol. Biotechnol. 2010, 86, 813-823. [CrossRef] [PubMed]

69. Crowley, S.; Mahony, J.; van Sinderen, D. Current Perspectives on Antifungal Lactic Acid Bacteria as Natural Bio-Preservatives. Trends Food Sci. Technol. 2013, 33, 93-109. [CrossRef]

70. Bulgasem, B.Y.; Lani, M.N.; Hassan, Z.; Yusoff, W.M.W.; Fnaish, S.G. Antifungal Activity of Lactic Acid Bacteria Strains Isolated from Natural Honey against Pathogenic Candida Species. Mycobiology 2016, 44, 302-309. [CrossRef] [PubMed]

71. Marie, K.P.; Ngoufack François, Z.; Edith Marius, F.K.; Ciobotaru, O.; Matei, F.; Cornea, C.P.; Israel-Roming, F. Antifungal Activity of Lactic Acid Bacteria Isolated from Peanuts, Gari, and Orange Fruit Juice against Food Aflatoxigenic Molds. Food Biotechnol. 2018, 32, 237-256. [CrossRef]

72. Coloretti, F.; Carri, S.; Armaforte, E.; Chiavari, C.; Grazia, L.; Zambonelli, C. Antifungal Activity of Lactobacilli Isolated from Salami. FEMS Microbiol. Lett. 2007, 271, 245-250. [CrossRef]

73. Voulgari, K.; Hatzikamari, M.; Delepoglou, A.; Georgakopoulos, P.; Litopoulou-Tzanetaki, E.; Tzanetakis, N. Antifungal Activity of Non-Starter Lactic Acid Bacteria Isolates from Dairy Products. Food Control 2010, 21, 136-142. [CrossRef]

74. Arena, M.P.; Silvain, A.; Normanno, G.; Grieco, F.; Drider, D.; Spano, G.; Fiocco, D. Use of Lactobacillus Plantarum Strains as a Bio-Control Strategy against Food-Borne Pathogenic Microorganisms. Front. Microbiol. 2016, 7, 464. [CrossRef] [PubMed] 
75. Tremonte, P.; Pannella, G.; Succi, M.; Luca, T.; Sturchio, M.; Coppola, R.; Luongo, D.; Sorrentino, E. Antimicrobial Activity of Lactobacillus Plantarum Strains Isolated from Different Environments: A Preliminary Study. Int. Food Res. J. 2017, 24, 852-859.

76. Sorrentino, E.; Tremonte, P.; Succi, M.; Iorizzo, M.; Pannella, G.; Lombardi, S.J.; Sturchio, M.; Coppola, R. Detection of Antilisterial Activity of 3-Phenyllactic Acid Using Listeria Innocua as a Model. Front. Microbiol. 2018, 9, 1373. [CrossRef] [PubMed]

77. Le Lay, C.; Coton, E.; Le Blay, G.; Chobert, J.-M.; Haertlé, T.; Choiset, Y.; Van Long, N.N.; Meslet-Cladière, L.; Mounier, J. Identification and Quantification of Antifungal Compounds Produced by Lactic Acid Bacteria and Propionibacteria. Int. J. Food Microbiol. 2016, 239, 79-85. [CrossRef]

78. Cortés-Zavaleta, O.; López-Malo, A.; Hernández-Mendoza, A.; García, H.S. Antifungal Activity of Lactobacilli and Its Relationship with 3-Phenyllactic Acid Production. Int. J. Food Microbiol. 2014, 173, 30-35. [CrossRef]

79. Kleerebezem, M.; Hols, P.; Bernard, E.; Rolain, T.; Zhou, M.; Siezen, R.J.; Bron, P.A. The Extracellular Biology of the Lactobacilli. FEMS Microbiol. Rev. 2010, 34, 199-230. [CrossRef]

80. Kinoshita, H.; Uchida, H.; Kawai, Y.; Kawasaki, T.; Wakahara, N.; Matsuo, H.; Watanabe, M.; Kitazawa, H.; Ohnuma, S.; Miura, K.; et al. Cell Surface Lactobacillus Plantarum LA 318 Glyceraldehyde-3-Phosphate Dehydrogenase (GAPDH) Adheres to Human Colonic Mucin. J. Appl. Microbiol. 2008, 104, 1667-1674. [CrossRef] [PubMed]

81. Åvall-Jääskeläinen, S.; Palva, A. Lactobacillus Surface Layers and Their Applications. FEMS Microbiol. Rev. 2005, 29, 511-529. [CrossRef]

82. Janashia, I.; Choiset, Y.; Jozefiak, D.; Déniel, F.; Coton, E.; Moosavi-Movahedi, A.A.; Chanishvili, N.; Haertlé, T. Beneficial Protective Role of Endogenous Lactic Acid Bacteria Against Mycotic Contamination of Honeybee Beebread. Probiotics Antimicrob. Proteins 2018, 10, 638-646. [CrossRef]

83. Siedler, S.; Balti, R.; Neves, A.R. Bioprotective Mechanisms of Lactic Acid Bacteria against Fungal Spoilage of Food. Food Biotechnol. Plant Biotechnol. 2019, 56, 138-146. [CrossRef]

84. Vásquez, A.; Forsgren, E.; Fries, I.; Paxton, R.J.; Flaberg, E.; Szekely, L.; Olofsson, T.C. Symbionts as Major Modulators of Insect Health: Lactic Acid Bacteria and Honeybees. PLoS ONE 2012, 7, e33188. [CrossRef]

85. Alberoni, D.; Baffoni, L.; Gaggìa, F.; Ryan, P.M.; Murphy, K.; Ross, P.R.; Stanton, C.; Di Gioia, D. Impact of Beneficial Bacteria Supplementation on the Gut Microbiota, Colony Development and Productivity of Apis Mellifera L. Benef. Microbes 2018, 9 , 269-278. [CrossRef] [PubMed]

86. Schwarz, R.S.; Moran, N.A.; Evans, J.D. Early Gut Colonizers Shape Parasite Susceptibility and Microbiota Composition in Honey Bee Workers. Proc. Natl. Acad. Sci. USA 2016, 113, 9345. [CrossRef] [PubMed]

87. Santarmaki, V.; Kourkoutas, Y.; Zoumpopoulou, G.; Mavrogonatou, E.; Kiourtzidis, M.; Chorianopoulos, N.; Tassou, C.; Tsakalidou, E.; Simopoulos, C.; Ypsilantis, P. Survival, Intestinal Mucosa Adhesion, and Immunomodulatory Potential of Lactobacillus Plantarum Strains. Curr. Microbiol. 2017, 74, 1061-1067. [CrossRef] [PubMed]

88. Tamarit, D.; Ellegaard, K.M.; Wikander, J.; Olofsson, T.; Vásquez, A.; Andersson, S.G.E. Functionally Structured Genomes in Lactobacillus Kunkeei Colonizing the Honey Crop and Food Products of Honeybees and Stingless Bees. Genome Biol. Evol. 2015, 7, 1455-1473. [CrossRef] [PubMed]

89. Salas-Jara, M.J.; Ilabaca, A.; Vega, M.; García, A. Biofilm Forming Lactobacillus: New Challenges for the Development of Probiotics. Microorganisms 2016, 4, 35. [CrossRef]

90. Berríos, P.; Fuentes, J.A.; Salas, D.; Carreño, A.; Aldea, P.; Fernández, F.; Trombert, A.N. Inhibitory Effect of Biofilm-Forming Lactobacillus Kunkeei Strains against Virulent Pseudomonas Aeruginosa in Vitro and in Honeycomb Moth (Galleria Mellonella) Infection Model. Benef. Microbes 2018, 9, 257-268. [CrossRef]

91. Janashia, I.; Choiset, Y.; Rabesona, H.; Hwanhlem, N.; Bakuradze, N.; Chanishvili, N.; Haertlé, T. Protection of Honeybee Apis Mellifera by Its Endogenous and Exogenous Lactic Flora against Bacterial Infections. Ann. Agrar. Sci. 2016, 14, 177-181. [CrossRef]

92. Lee, I.-C.; Caggianiello, G.; van Swam, I.I.; Taverne, N.; Meijerink, M.; Bron, P.A.; Spano, G.; Kleerebezem, M. Strain-Specific Features of Extracellular Polysaccharides and Their Impact on Lactobacillus Plantarum-Host Interactions. Appl. Environ. Microbiol. 2016, 82, 3959. [CrossRef]

93. Flemming, H.-C.; Neu, T.R.; Wozniak, D.J. The EPS Matrix: The “House of Biofilm Cells". J. Bacteriol. 2007, 189, 7945. [CrossRef]

94. Limoli, D.H.; Jones, C.J.; Wozniak, D.J. Bacterial Extracellular Polysaccharides in Biofilm Formation and Function. Microbiol. Spectr. 2015, 3. [CrossRef]

95. Neu, T.R.; Lawrence, J.R. Chapter 37-Extracellular polymeric substances in microbial biofilms. In Microbial Glycobiology; Holst, O., Brennan, P.J., von Itzstein, M., Moran, A.P., Eds.; Academic Press: San Diego, CA, USA, 2010; pp. 733-758. ISBN 978-0-12-374546-0.

96. Butler, Ė.; Alsterfjord, M.; Olofsson, T.C.; Karlsson, C.; Malmström, J.; Vásquez, A. Proteins of Novel Lactic Acid Bacteria from Apis Mellifera Mellifera: An Insight into the Production of Known Extra-Cellular Proteins during Microbial Stress. BMC Microbiol. 2013, 13, 235. [CrossRef] [PubMed]

97. Karatan, E.; Watnick, P. Signals, Regulatory Networks, and Materials That Build and Break Bacterial Biofilms. Microbiol. Mol. Biol. Rev. 2009, 73, 310. [CrossRef] [PubMed]

98. Caggianiello, G.; Kleerebezem, M.; Spano, G. Exopolysaccharides Produced by Lactic Acid Bacteria: From Health-Promoting Benefits to Stress Tolerance Mechanisms. Appl. Microbiol. Biotechnol. 2016, 100, 3877-3886. [CrossRef]

99. Weirich, G.F.; Collins, A.M.; Williams, V.P. Antioxidant Enzymes in the Honey Bee, Apis Mellifera. Apidologie 2002, 33, 3-14. [CrossRef] 
100. Nikolić, T.V.; Purać, J.; Orčić, S.; Kojić, D.; Vujanović, D.; Stanimirović, Z.; Gržetić, I.; Ilijević, K.; Šikoparija, B.; Blagojević, D.P. Environmental effects on superoxide dismutase and catalase activity and expression in honey bee. Arch. Insect Biochem. Physiol. 2015, 90, 181-194. [CrossRef] [PubMed]

101. Collins, A.M.; Williams, V.; Evans, J.D. Sperm Storage and Antioxidative Enzyme Expression in the Honey Bee, Apis Mellifera. Insect Mol. Biol. 2004, 13, 141-146. [CrossRef] [PubMed]

102. Balieira, K.V.B.; Mazzo, M.; Bizerra, P.F.V.; Guimarães, A.R.D.J.S.; Nicodemo, D.; Mingatto, F.E. Imidacloprid-Induced Oxidative Stress in Honey Bees and the Antioxidant Action of Caffeine. Apidologie 2018, 49, 562-572. [CrossRef]

103. Morimoto, T.; Kojima, Y.; Toki, T.; Komeda, Y.; Yoshiyama, M.; Kimura, K.; Nirasawa, K.; Kadowaki, T. The Habitat Disruption Induces Immune-Suppression and Oxidative Stress in Honey Bees. Ecol. Evol. 2011, 1, 201-217. [CrossRef]

104. Banerjee, B.D.; Seth, V.; Ahmed, R.S. Pesticide-Induced Oxidative Stress: Perspective and Trends. Rev. Environ. Health 2001, 16, 1-40. [CrossRef]

105. Simone-Finstrom, M.; Li-Byarlay, H.; Huang, M.H.; Strand, M.K.; Rueppell, O.; Tarpy, D.R. Migratory Management and Environmental Conditions Affect Lifespan and Oxidative Stress in Honey Bees. Sci. Rep. 2016, 6, 32023. [CrossRef] [PubMed]

106. Claudianos, C.; Ranson, H.; Johnson, R.M.; Biswas, S.; Schuler, M.A.; Berenbaum, M.R.; Feyereisen, R.; Oakeshott, J.G. A Deficit of Detoxification Enzymes: Pesticide Sensitivity and Environmental Response in the Honeybee. Insect Mol. Biol. 2006, 15, 615-636. [CrossRef] [PubMed]

107. Belsky, J.; Joshi, N.K. Impact of Biotic and Abiotic Stressors on Managed and Feral Bees. Insects 2019, 10, 233. [CrossRef] [PubMed]

108. Drossart, M.; Gérard, M. Beyond the Decline of Wild Bees: Optimizing Conservation Measures and Bringing Together the Actors. Insects 2020, 11, 649. [CrossRef]

109. Blot, N.; Veillat, L.; Rouzé, R.; Delatte, H. Glyphosate, but Not Its Metabolite AMPA, Alters the Honeybee Gut Microbiota. PLoS ONE 2019, 14, e0215466. [CrossRef] [PubMed]

110. Li, X.; Ma, W.; Shen, J.; Long, D.; Feng, Y.; Su, W.; Xu, K.; Du, Y.; Jiang, Y. Tolerance and Response of Two Honeybee Species Apis Cerana and Apis Mellifera to High Temperature and Relative Humidity. PLoS ONE 2019, 14, e0217921. [CrossRef]

111. Paris, L.; Roussel, M.; Pereira, B.; Delbac, F.; Diogon, M. Disruption of Oxidative Balance in the Gut of the Western Honeybee Apis Mellifera Exposed to the Intracellular Parasite Nosema Ceranae and to the Insecticide Fipronil. Microb. Biotechnol. 2017, 10, 1702-1717. [CrossRef]

112. Feldhaar, H.; Otti, O. Pollutants and Their Interaction with Diseases of Social Hymenoptera. Insects 2020, 11, 153. [CrossRef]

113. Seehuus, S.-C.; Norberg, K.; Gimsa, U.; Krekling, T.; Amdam, G.V. Reproductive Protein Protects Functionally Sterile Honey Bee Workers from Oxidative Stress. Proc. Natl. Acad. Sci. USA 2006, 103, 962. [CrossRef]

114. Feng, T.; Wang, J. Oxidative Stress Tolerance and Antioxidant Capacity of Lactic Acid Bacteria as Probiotic: A Systematic Review. Gut Microbes 2020, 12, 1801944. [CrossRef]

115. Lin, M.-Y.; Yen, C.-L. Antioxidative Ability of Lactic Acid Bacteria. J. Agric. Food Chem. 1999, 47, 1460-1466. [CrossRef] [PubMed]

116. Mishra, V.; Shah, C.; Mokashe, N.; Chavan, R.; Yadav, H.; Prajapati, J. Probiotics as Potential Antioxidants: A Systematic Review. J. Agric. Food Chem. 2015, 63, 3615-3626. [CrossRef] [PubMed]

117. Das, D. Arun Goyal Antioxidant Activity and $\gamma$-Aminobutyric Acid (GABA) Producing Ability of Probiotic Lactobacillus Plantarum DM5 Isolated from Marcha of Sikkim. Lebensm. Wiss. Ie Technol. Food Sci. Technol. Sci. Technol. Aliment. 2015, 61, 263-268. [CrossRef]

118. Kullisaar, T.; Zilmer, M.; Mikelsaar, M.; Vihalemm, T.; Annuk, H.; Kairane, C.; Kilk, A. Two Antioxidative Lactobacilli Strains as Promising Probiotics. Int. J. Food Microbiol. 2002, 72, 215-224. [CrossRef]

119. Chanput, W.; Krueyos, N.; Ritthiruangdej, P. Anti-Oxidative Assays as Markers for Anti-Inflammatory Activity of Flavonoids. Int. Immunopharmacol. 2016, 40, 170-175. [CrossRef] [PubMed]

120. Arnao, M.B.; Cano, A.; Acosta, M. The Hydrophilic and Lipophilic Contribution to Total Antioxidant Activity. Food Chem. 2001, 73, 239-244. [CrossRef] 